\title{
Enriching the Child's World in Selected Poems by Christina Rossetti, Shel Silverstein, and Valerie Bloom: Insights into Children's Literature
}

\author{
Dr. Abdel Mohsen Ibrahim Hashim \\ Associate Professor of English Literature, Department of \\ English, Faculty of Arts, The New Valley University, Egypt.
}

\begin{abstract}
:
Employing English language children's literature as a theoretical framework that sheds light on the definition of the term and its historical development, this paper strives to explore a variety of insights into enriching the child's world. To achieve this goal, the paper focuses on selected poems for children written by three poets who have varied backgrounds of place and time. The first of these figures is the nineteenthcentury English poet Christina Rossetti (1830 -1894); the second is the twentieth-century American poet and cartoonist Shel Silverstein (1930-1999); and the third is the contemporary Jamaican-born poet Valerie Bloom (b.1956). Depending on the poems selected for discussion, the researcher argues that each of these authors writes a kind of poetry that enriches the child's world in a specific way. The various ideas and experiences offered by the three writers in the selected poems are beautifully integrated, providing young readers with comprehensive insights and useful mechanisms that enable them to achieve success and lead a happy life.
\end{abstract}

Keywords: Children's Literature, insights, poems, Christina Rossetti, Shel Silverstein, Valerie Bloom 


\title{
المالفص العربي
}

\section{إثراء عالم الطفل في تصائد هختارة لـ "كريستينا روسيتي" \\ و"شيل سيلفراستين" و"فاليري بلوم": رؤى في أدب الأطفال}

\author{
د. عبد المسن إبراهيم هاشيم \\ أستاذ مساعد الأدب الإنجليزي- قسم اللغة الإنجليزية \\ كلية الآداب- جامعة الوادي الجديد، مصر.
}

تقدم هذه الدراسة رؤى متتوعة في إثراء عالم الطفل في قصائد مختارة لثلاثة من الثعراء ذوي الخلفيات المتفاوتة في المكان والزمان. وهؤلاء الثعراء هم "كريتينا روسيتى" (1830- 1890)، الثاعرة الإنجليزية المعروفة والتي عاشت خلال القرن التاسع عشر ، و "شيل سيلفرستين" (1930- 1999)، الثاعر والرسام الأمريكي المشهور والذي ينتمي إلى القرن العشرين، و"فاليري بلوم"، الثاعرة المعاصرة التي ولدت عام 1956 في جامايكا ثم انتقلت للعيش والدراسة في إنجلترا حيث ذاع صيتها هناك كمؤلفة متميزة لكتب الأطفال. وفي ضوء القصائد المختارة في هذه الدراسة، يرى الباحث أن الشعراء الثلاثة يثرون عالم الطفل بشكلٍ شيقِ ومتميزٍ ، كلٌ بطريقةٍ معينةٍٍ. هذا، وإن اختلفت الأفكار وتباينت الرؤى التي يعرضها المؤلفون الثلاثة في كتاباتهم، فإنها تتلاقى معا لتشكل كلاً متناغماً يقدم للقارئ الطفل خبرات ثرية ووجهات نظر متتوعة تثري عالمه وتوسع مداركه وتزوده بالآليات اللازمة التي تمكنه من تحقيق النجاح والسعادة في حياته.

الكلمات الالالية: أدب الأطفال، رؤى، قصائد، كريستينا روسيتي، شيل سيلفرستين، فاليري بلوم. 
Enriching the Child's World in Selected Poems by Christina Rossetti, Shel

Silverstein, and Valerie Bloom: Insights into Children's Literature Dr. Abdel Mohsen Ibrahim Hashim
مجلة وادي التيل للاراسات والبحوث الإنسانية والاجتماعية والتربوية (مجلة علمية محكمة)
Enriching the Child's World in Selected Poems by Christina Rossetti, Shel Silverstein, and Valerie Bloom: Insights into Children's Literature

\section{Dr. Abdel Mohsen Ibrahim Hashim}

Who has seen the wind?

Neither you nor I;

But when the trees bow down their heads

The wind is passing by.

- (Rossetti, Selected Poems 140)

Oh, if you're a bird, be an early bird

And catch the worm for your breakfast plate.

If you're a bird, be an early early bird-

But if you're a worm, sleep late.

- (Silverstein, A Light in the Attic 169)

The river's a baby,

He gurgles and hums,

And sounds like he's happily

Sucking his thumbs.

— (Bloom, Let Me Touch The Sky 41)

Children are like soft flowers that need care and attention in order to bloom and grow properly. Hence, the process of developing their characters and preparing them for real life has been a significant interest of parents, educators, and psychologists. Writers have also played a major role in the child development process through children's literature which is recognized as a highly effective tool for instilling good 
habits, noble values, and desirable attitudes; it is also an inspiring doorway that takes the child into an exciting world of amusement and instruction. However, critics and scholars differ in defining children's literature. Some view it as a subject that has been brought into mainstream literature, whereas others see it as a genre in its own, with distinctive norms and characteristics. Whether regarded as a part of adult literature or seen as a separate genre, children's literature can generally be defined as that body of literary works that address children, meet their needs, and expose them to the real world, with the aim to entertain, inform, and instruct them.

According to Perry Nodelman, the first true children's book in English did not come into sight until 1744 when the British writer and publisher John Newbery, the father of children's literature as he was called, published A Little Pretty PocketBook: Intended for the Instruction and Amusement of Little Master Tommy and Pretty Miss Polly. Interestingly, this collection of games and rhymes was sold with a free gift, a ball for a boy or a pincushion for a girl (17). Nevertheless, legends, nursery rhymes, and fairy tales were narrated for children since the dawn of human civilization. These forms of literature were orally transmitted from one generation to the next. In the mid-fifteenth century, hornbooks ${ }^{1}$ were invented to teach children the alphabet, numerals, and prayers. Significantly, the advent of printing in England in 1476 at the hands of William Caxton (Tokunaga 151) led to the emergence of books which children could enjoy, though these books did not address young readers as a separate audience. As children learn to read, they "also take over adult books which appeal to them, a process helped by the fact that the early printed literature in any society is likely to draw on traditional stories which...appeal to every age group" (Hunt 4). However, a significant development of children's books 
Enriching the Child's World in Selected Poems by Christina Rossetti, Shel Silverstein, and Valerie Bloom: Insights into Children's Literature Dr. Abdel Mohsen Ibrahim Hashim

مجلة وادي النيل للاراسات والبحوث الإنسانية والاجتماعية والتربوية (مجلة علمية محكمة)

took place when Caxton printed and published an English translation of Aesop's Fables ${ }^{2}$ in 1484 and Sir Thomas Malory's Le Morte d'Arthur ${ }^{3}$ or The Death of Arthur in 1485.

In the sixteenth century, the works written for children were mainly moralistic and didactic. Therefore, there was a rise in the books intended for educational purposes such as the courtesy books and etiquette guides; these were works that taught children the proper bahaviour, morals, and etiquette. Prominent among these works was A Handbook on Good Manners for Children: De Civilitate Morum Puerilium Libellus that was first published in Latin by the Dutch humanist scholar Erasmus of Rotterdam in 1530 and translated into English for the first time in 1532 by Robert Whittington. In A Handbook on Good Manners for Children, Erasmus guides the child into how to master table manners, how to get dressed, how to address one's elders, how to speak to members of the opposite sex, how to show respect for others, and many other good manners.

In the seventeenth century, the emergence of chapbooks satisfied children's need for knowing about popular literature. Usually sold by chapmen or peddlers, a chapbook was something like a pamphlet or a pocket-sized booklet that contained fairy tales, legends, ballads, poems, farces, traditional stories, or religious tracts. It is noteworthy that the second half of the seventeenth century witnessed the production of the first children's picture-book. This was precisely in 1658 when the Czech philosopher and pedagogue John Comenius, who was widely recognized as the father of modern education, published Orbis Sensualism Pictus or The World of Things Obvious to the Senses Drawn in Pictures. The book was originally published by Comenius in Latin and German, and a year later, it was translated into English by 
مجلة وادي النيل للاراسات والبحوث الإنسانية والاجتماعية والتربوية (مجلة علمية محكمة)

(ISSN : 2536 - 9555)

Charles Hoole (Murphy 200). Towards the end of the century, the English thinker John Locke and his views on education greatly influenced the development of children's literature. In his well-known work An Essay Concerning Human Understanding (1690), Locke emphasizes the notion that the mind of the child at birth is like a 'tabula rasa', that is, a blank state or a white page which is gradually inscribed with the data or knowledge deriving from sensory experience (Androne 75). Therefore, "writers for children adopted and adapted Lockean principles in order to shape children on all social levels and prepare them for life in a swiftly changing, upwardly mobile society" (Rosenthal). However, Locke's comparison of the minds of young children to passive blank states reflected his disbelief in the existence of the child's innate faculties, a view that was later criticized by many critics and academics.

The eighteenth century was the starting point for establishing a solid foundation for children's literature written in English. During that century, authors turned to compose books that were solely meant for children, books that did not confine its focus to instructing children but also included entertainment as an essential consideration. Even famous books that were mainly written for adults were adapted to suit and amuse children such as Daniel Defoe's Robinson Crusoe (1719) and Jonathan Swift's Gulliver's Travels (1726). In 1729, Charles Perrault's Contes de ma Mère l'Oye, a fairy tale collection that was originally published in French in 1695, was first translated into English as Tales of My Mother Goose. A compilation of Mother Goose rhymes titled Mother Goose's Melody, or, Sonnets for the Cradle was published in 1765 by John Newbery. In addition to his influential work A Little Pretty Pocket-Book, Newbery published many other books for children such as The Renowned History of Giles Gingerbread: 
Enriching the Child's World in Selected Poems by Christina Rossetti, Shel Silverstein, and Valerie Bloom: Insights into Children's Literature Dr. Abdel Mohsen Ibrahim Hashim

مجلة وادي النيل للاراسات والبحوث الإنسانية والاجتماعية و التربوية (مجلة علمية محكمة)

A Little Boy Who Lived Upon Learning (1764) and The History of Little Goody Two-Shoes (1765). A great influence on children's literature during that period was Jean-Jacques Rousseau's Emile (1762), a significant work in which the great philosopher emphasizes the importance of the child's moral development. The success achieved by the book led to an evident rise in children's moralistic tales. As a result, books concentrating on instilling proper behaviour in young readers and teaching them how to be good human beings became very popular at that time. Before the eighteenth century came to a close, precisely in 1791, the bookseller and publisher Elizabeth Newbery, John Newbery's successor, had published the first children's edition of Tales from the Arabian Nights, one of the most well-known works in Arabic literature. The book included many interesting classical stories such as "Sinbad the Sailor", "Sheherezade", "Aladdin and his Magical Lamp", and "Ali Baba and the Forty Thieves".

In the nineteenth century, English language children's literature steadily continued the flourishing phase it had started in the earlier century and began to go into the direction of its golden age, with a remarkable focus on fun, adventure, tales of family life, and modern fantasy. The richness of Victorian literature was reflected in the works written for young readers. Early in the century, two brothers from Germany, Jacob and Wilhelm Grimm, collected an enormous number of interesting folktales and published them in a collection titled Kinder-und Hausmärchen (1812) or Grimms' Nursery and Household Tales as it was translated into English. Having traveled throughout all Europe to collect tales for children, the Danish writer Hans Christian Anderson published his significant work titled Fairy Tales in 1835 as the first book that contained a modern bulk of fairy tales. Widely 
مجلة وادي النيل للاراسات والبحوث الإنسانية والاجتماعية والتربوية (مجلة علمية محكمة)

(ISSN : 2536 - 9555)

known as the father of modern fairy tale and fantasy, Anderson had a significant impact on the development of children's literature. In his own words, "My fairy tales and stories have been translated into over one hundred fifty languages" (qtd. in Petersen 277). Famous among these fairy tales are The Little Mermaid, The Emperor's New Clothes, The Snow Queen, The Wild Swans, The Red Shoes, The Naughty Boy, and The Little Match Girl. More Works that reflected the rise of modern fantasy in children's books are Lewis Carroll's Alice's Adventures in Wonderland (1865) and Joseph Jacobs' fairy tales volumes: English Fairy Tales (1890) and More English Fairy Tales (1893). Stories of family life in the Victorian era were narrated in Louisa May Alcott's Little Women (1868), and the bond between mother and child was depicted in Christina Rossetti's Sing-Song: A Nursery Rhyme Book (1872). Besides, adventure was highlighted in Mark Twain"s Adventures of Tom Sawyer (1876) and Robert Louis Stevenson's Treasure Island (1880).

In the twentieth century, children's literature in Englishspeaking countries reached a stage of maturity and became "a field of its own, with its own space in public libraries, its own graduate programs, and its own respected journals" (Stevenson 428). Early in the century, fantasy writers made a notable contribution to the promotion of children's literature through works such as L. Frank Baum's The Wonderful Wizard of Oz (1900), Beatrix Potter's The Tale of Peter Rabbit (1901), J. M. Barrie's Peter Pan (1904), and Kenneth Grahame's The Wind in the Willows (1908). Working as a bridge between England where she was born, and America where she finally settled, the novelist and playwright Frances Hodgson Burnett wrote two significant classics of children's literature, A Little Princess (1905) and The Secret Garden (1911), focusing on girls rather than boys as protagonists. In 
Enriching the Child's World in Selected Poems by Christina Rossetti, Shel Silverstein, and Valerie Bloom: Insights into Children's Literature Dr. Abdel Mohsen Ibrahim Hashim

مجلة وادي النيل للاراسات والبحوث الإنسانية والاجتماعية والتربوية (مجلة علمية محكمة)

1920, Hugh Lofting published his famous work The Story of Doctor Dolittle in which the hero is a physician who can talk to animals. The English writer and poet A. A. Milne is mainly remembered for his Winnie-the-Pooh (1926) which stood at that time as one of the most popular collections of children's short stories. In this significant work, Milne tells young readers about Winnie the Pooh, the main character in the stories whose name was taken from a teddy bear owned by the writer's son. A favourite author for young readers and their parents was Dr. Seuss who wrote many interesting books for children the first of which, And to Think I Saw It on Mulberry Street, was published in 1937.

Undoubtedly, the two World Wars and the wound they had caused for humanity affected the content of children's literature and made a shift in its focus. For twentieth-century children; war was no longer a time of heroics as the traditional stories had previously shown. Instead, it was a dreadful event reflecting pain, suffering, and the homelessness of children and families. Hence, the literature written for children at that time urged the young generations to stand for peace, love, and kindness, teaching them to construct a better world out of the chaos created by two destructive world wars. Well-known among the anti-war works written for children in the twentieth-century are Munro Leaf's The Story of Ferdinand (1936), Anne Frank's The Diary of a Young Girl (1947), Ian Serraillier's The Silver Sword (1956), Michael Foreman's War and Peas (1974), Robert Westall's The Machine Gunners (1975), and Eleanor Coerr's famous novel Sadako and the Thousand Paper Cranes (1977) which tells the real story of Sadako Sasaki, a two-year-old Japanese girl who was killed by the atomic bomb which the United States dropped on Hiroshima during World War II. Since then, 
مجلة وادي النيل للاراسات والبحوث الإنسانية والاجتماعية والتربوية (مجلة علمية محكمة)

(ISSN : 2536 - 9555)

Sadako's origami paper cranes have stood as a symbol of peace all over the world.

As one of the most important British authors for children in the twentieth century, Roald Dahl enriched the child's library with great works such as James and the Giant Peach (1961), Charlie and the Chocolate Factory (1964), and Fantastic Mr. Fox (1970). An influential poet whose work left a clear mark on children's literature in that century was Shel Silverstein. His poetry collections, such as The Giving Tree (1964) and Where the Sidewalk Ends: The Poems and Drawings of Shel Silverstein (1974), among others, captivated young readers by their vivid portrayals and irresistible beauty. The 1980s witnessed the publication of significant children's books such as Sarah, Plain and Tall (1985) by Patricia MacLachlan and Hatchet (1987) by Gary James Paulsen. In the 1990s, children's literature was promoted by influential works such as Lois Lowry's The Giver (1993), Louis Sachar's Holes (1998), and Philip Pullman's His Dark Materials, an epic trilogy of fantasy novels including Northern Lights (1995), The Subtle Knife (1997) and The Amber Spyglass (2000).

Thus, the twentieth century was a period in which society recognized the importance of childhood and the literature written for young readers. In addition to educators and writers, psychologists and anthropologists devoted a great part of their energy to children's studies. The growing significance of children's literature was also reflected in the unique place children's books occupied in the departments of the publishing companies. Reviews of children's book began to appear for the first time. Specialized magazines in children's literature, like The Horn Book Magazine and others, became very common. Furthermore, awards in the field of children's literature were created. For example, The Newbery Medal was established in 1922 to be awarded annually for the author who had written 
Enriching the Child's World in Selected Poems by Christina Rossetti, Shel

Silverstein, and Valerie Bloom: Insights into Children's Literature

Dr. Abdel Mohsen Ibrahim Hashim

مجلة وادي النيل للاراسات والبحوث الإنسانية والاجتماعية و التربوية (مجلة علمية محكمة)

the best children's work in the earlier year. The medal took its name from the famous writer and bookseller John Newbery. To honour artists in the field of children's literature, the Caldecott Medal was designed in 1937 to be given to the artist producing the most outstanding picture-book each year. The award was named in honour of Randolph Caldecott, an eminent British artist and illustrator.

The early twenty-first century brought a remarkable development in the field of children's literature. With the vast advancement in portable technologies such as laptops, tablets, kindle, and smartphones, digital books have become very common, and children have shown unsurpassable skills in using these devices. Remarkably, fairy tales have developed to best reflect the world through the eyes of a child. They sometimes "depict illusory events taking place in fairy lands full of miracles...or offer a peculiar brand of magic realism in which supernatural events happen, and weird characters wander around a realistic environment" (Kumberg). Besides, a multicultural dimension has characterized children's literature as writers of many cultures have made significant contributions to the field, enriching the child's world with varied backgrounds and diverse insights. Moreover, there has been a change in the subject matter dealt with in children's literature. Topics that young readers' books did not previously dare to handle are now presented in a simplified manner that enables the child to have an idea about the risks of a negative issue and know how to face it in real life. For instance, children above ten may now read stories about suicide, child abuse, illegitimate pregnancy, drugs, and racism, among many other issues. In this way, the literature written for children, in addition to working as a means of entertainment, gives young readers the chance to explore the challenges of a rapidly 
changing world, familiarizing them with the dangers they may confront in their lives together with good models in the books they read to follow when they grow up into responsible people. Prominent among the works written for children in the first two decades of the twenty-first century are Mark Haddon's The Curious Incident of the Dog in the Night-Time (2003), J. K. Rowling's well-known novel Harry Potter and the Half-Blood Prince (2005), and Jeff Kinney's Diary of a Wimpy Kid (2007). Other works are Jennifer Richard Jacobson's Small as an Elephant (2011), Valerie Bloom's Mighty Mountains, Swirling Seas (2015), Michael Morpurgo's Flamingo Boy (2018), and David Walliams' funny book Fing (2019) that tells the story of the Meeks and their child Myrtle who has everything but still wants more.

In their poetry for children, specifically the poems under discussion, Christina Rossetti, Shel Silverstein, and Valerie Bloom enrich the child's world, each from a particular perspective. To start with Rossetti whose poems warmly assert maternal love, develop a sense of beauty, stimulate intelligence, excite the imagination, and satisfy the curiosity of children. Expressing the deep love a mother feels for her infant and depicting their intimate relationship, Rossetti writes:

Love me, -- I love you,

Love me, my baby;

Sing it high, sing it low,

Sing it as may be.

Mother's arms under you,

Her eyes above you;

Sing it high, sing it low,

Love me -- I love you. (Sing-Song 2) 
Enriching the Child's World in Selected Poems by Christina Rossetti, Shel

Silverstein, and Valerie Bloom: Insights into Children's Literature

Dr. Abdel Mohsen Ibrahim Hashim

مجلة وادي النيل للاراسات والبحوث الإنسانية والاجتماعية والتربوية (مجلة علمية محكمة)

In this lullaby poem, maternal love is presented as an emotion that not only helps young children grow up well but also makes them feel safe, comforted, and valued. The mother is portrayed as a caregiver and a nurturer who provides her baby with care, safety, and love. At the same time, she happily enjoys the unspoken love the young child generously shows for her. Thus, this supreme kind of love between mother and child is mutual, selfless, sincere, and unconditional. Apostrophe is used throughout the poem, showing how happy and excited the mother is when she talks to her baby. Obviously, the language the poet employs is simple, clear, and suitable for addressing a young child. The repetition of the words 'love' and 'sing' throughout the lines implies an atmosphere of happiness, relief, affection, warmth, and satisfaction. In lines 1 and 2 of the second stanza (Mother's arms under you, / Her eyes above you), the poet asks her baby to feel safe, calm, and serene as her maternal arms and caring eyes are always there, providing compassion, comfort, and protection. That the poem starts and ends with the same line 'Love me -- I love you' is very significant, as if the poet wants to say that the mother/child relationship is a strong one based on nonstop maternal love, and is therefore everlasting.

In the time of hardship, maternal love emerges, surrounding the child with strength and relief. This is what Rossetti maintains in the following lines:

Crying, my little one, footsore and weary?

Fall asleep, pretty one, warm on my shoulder:

I must tramp on through the winter night dreary, While the snow falls on me colder and colder.

You are my one, and I have not another;

Sleep soft, my darling, my trouble and treasure; 
مجلة وادي النيل للاراسات والبحوث الإنسانية و الاجتماعية والتربوية (مجلة علمية محكمة)

(ISSN : 2536 - 9555)

Sleep warm and soft in the arms of your mother,

Dreaming of pretty things, dreaming of pleasure.

(Poems and Prose 200)

The lines depict the child complaining of pain and fatigue in a cold, snowy night. At once, the mother appears as a savior and supplier of comfort and protection. She caringly urges 'her little one' to seek shelter in her maternal shoulder. Enduring the trouble of harsh weather, the mother goes on walking in that dull winter night, not caring for 'the snow' that' falls on' her, 'colder and colder'. All that she wants is to keep her child away from cold and snow regardless of the suffering she may undergo. It is maternal love that makes the mother willingly bear all difficulties for the sake of saving and relieving her offspring. Feeling secure, the baby can now sleep in the mother's tender arms, dreaming of beautiful things, 'dreaming of pleasure'. Expressively, the mother speaker describes her child as her 'darling', 'trouble' and 'treasure'. That the child is her darling and treasure means that the child is the source of happiness and satisfaction for the mother. On the other hand, the child is her trouble in the sense that whatever hurts him/her disturbs the mother and makes her sad and disturbed, simply because, as she states in the poem, "You are my one, and I have not another'. The juxtaposition between the severe winter night and the caring mother emphasizes the meaning intended by the poet and reveals how maternal love is a lifeline that always guides and saves the child.

Another way in which Rossetti's poetry enriches the child's world is through developing young readers' sense of beauty and enhancing their aesthetic taste. In The Sense of Wonder, Rachel Carson reminds us:

A child's world is fresh and new and beautiful, full of wonder and excitement. It is our misfortune that for most of us that clear-eyed 
Enriching the Child's World in Selected Poems by Christina Rossetti, Shel

Silverstein, and Valerie Bloom: Insights into Children's Literature Dr. Abdel Mohsen Ibrahim Hashim

مجلة وادي النيل للاراسات والبحوث الإنسانية والاجتماعية والتربوية (مجلة علمية محكمة)

vision, that true instinct for what is beautiful and awe-inspiring, is dimmed and even lost before we reach adulthood. If I had influence with the good fairy who is supposed to preside over the christening of all children I should ask that her gift to each child in the world be a sense of wonder so indestructible that it would last throughout life as an unfailing antidote against the boredom and disenchantment of later years (42-43).

'The Rainbow' is a poem in which Rossetti portrays the natural sights whose beauty surpasses that of the man-made things. The poet writes:

Boats sail on the rivers,

And ships sail on the seas;

But clouds that sail across the sky

Are prettier than these.

There are bridges on the rivers,

As pretty as you please;

But the bow that bridges heaven,

And overtops the trees,

And builds a road from earth to sky,

Is prettier far than these. (Sing-Song 25)

Though man has created many pretty things, nature and its elements are still prettier. For example, boats and ships beautifully make their path into the rivers and the seas, yet 'clouds that sail across the sky', creating an amazing scene whose charm captivates the gazer, are more beautiful and more attractive. Likewise, the man-made bridges seen on the rivers capture the attention with their glamorous designs and shapes, yet the fascinating rainbow is 'prettier far than these' 
as it wonderfully 'bridges heaven' and 'overtops the trees', building a magnificent 'road from earth to sky'. Human hands are still unable to replicate the beauty of nature. Significantly, the poet uses the word 'but' in the third and seventh lines in order to contrast what is made by human beings with what is natural, concluding that the latter is lovelier and prettier. However, all these pretty things outlined in the poem, whether natural or man-made, develop children's sense of beauty and enhance their aesthetic taste.

In her poem 'Kookoorookoo! Kookoorookoo', Rossetti fascinates her young readers and evokes their sense of beauty by her vivid description of the daybreak which is pleasantly announced by the joyful sounds of the cock:

"Kookoorookoo! kookoorookoo!"

Crows the cock before the morn;

"Kikirikee! kikirikee!"

Roses in the east are born.

"Kookoorookoo! kookoorookoo!"

Early birds begin their singing;

"Kikirikee! kikirikee!"

The day, the day, the day is springing.

(Poems and Prose 199)

The lines draw a beautiful scene where the cock excitedly declares the start of a new day, roses are shown blooming very cheerfully, singing birds brighten up the place with their sweet melodies, and finally, the day suddenly springs like a new birth. Onomatopoeia is cleverly used by the poet, revealing the charming sounds of the cock, drawing attention to the lovely songs of birds, and enriching the lines with an impressive flow of music. Furthermore, the repetition of the word 'day' three times in the last line maintains the burst of the day into a new start. The diction the poet employs is simple, and the idea is easily grasped by children who can happily enjoy this 
Enriching the Child's World in Selected Poems by Christina Rossetti, Shel

Silverstein, and Valerie Bloom: Insights into Children's Literature Dr. Abdel Mohsen Ibrahim Hashim

مجلة وادي النيل للاراسات والبحوث الإنسانية والاجتماعية والتربوية (مجلة علمية محكمة)

marvelous atmosphere and can imaginatively realize the beauty of the new beginning.

Not only does Rossetti's poetry develop children's sense of the physical beauty evoked by nature, but it also deepens their feeling of the spiritual beauty that emerges when a creature, human or nonhuman, satisfactorily shares the same thing with another mate. These expressive meanings are embodied in 'Song' ('Two Doves upon the Selfsame Branch'), a poem in which Rossetti invites the child to contemplate how the union and harmony of many lovely couples in the natural world make those 'who look on them' feel thrilled and fascinated:

Two doves upon the selfsame branch,

Two lilies on a single stem,

Two butterflies upon one flower:--

O happy they who look on them. (Goblin Market 53)

The poet explains how two tender doves gratefully take part in the same branch, how two soft lilies delightfully grow up on one stem, and how two pretty butterflies agreeably rely on a single flower. Things turn out to be beautiful and meaningful when we benevolently share them with others. The passerby who watches these eye-catching sights can do nothing but become happy and captivated by this irresistible attractiveness. The vocabulary used by the poet in the above lines, such as 'doves', 'lilies', 'butterflies', 'flower', and 'happy', reveals an atmosphere of peacefulness, tenderness, cheerfulness, and beauty.

In addition to highlighting maternal love, developing children's sense of beauty, and promoting their aesthetic taste, Rossetti's poetry stimulates intelligence, excites the imagination, and satisfies the curiosity of the child. 'A Riddle' 
is a poem which requires young readers to think deeply and use their imaginative capabilities. The poet mentions:

There is one that has a head without an eye,

And there's one that has an eye without a head.

You may find the answer if you try;

And when all is said,

Half the answer hangs upon a thread.

(Sing-Song 74)

The riddle is simply stated and excitedly presented. Young readers need to concentrate and think imaginatively to know the two things which the lines describe. They are very curious to reach the answer. They are asked to know the thing that 'has a head without an eye' and the thing that 'has an eye without a head'. 'Half the answer', that is one of the two things, 'hangs upon a thread'. Young readers 'may find the answer', if they 'try' and read the poem to the end, as the last line will lead them to know one of the two things, and then it will be easy for them to guess the name of the other one. The answer is very inspiring. The first thing is the pin as it has a head and does not have any eyes or holes in it, and the second that is illustrated by the final line is the needle as it has an eye without a head and it really 'hangs upon a thread'. Arousing children's curiosity and interest, such riddles allow young readers to use their imagination and test their intelligence. Consequently, their world is deepened and enriched.

In fact, Rossetti's work reflects her fondness of writing riddles for children ${ }^{4}$. For instance, in 'A Pin Has a Head, But Has No Hair', she writes, "A pin has a head, but has no hair; / A clock has a face, but no mouth there; /... Rivers run, though they have no feet; / A saw has teeth, but it does not eat" (Selected Poems 139). Similarly, in her poem titled 'A City Plum Is Not a Plum', she addresses the intelligence of her child audience, stating, "A city plum is not a plum; / A dumb- 
Enriching the Child's World in Selected Poems by Christina Rossetti, Shel

Silverstein, and Valerie Bloom: Insights into Children's Literature Dr. Abdel Mohsen Ibrahim Hashim

مجلة وادي النيل للاراسات والبحوث الإنسانية والاجتماعية والتربوية (مجلة علمية محكمة)

bell is no bell, though dumb; / A party rat is not a rat; / A sailor's cat is not a cat" (Poetical Works 427). Relying on wordplay and rhyming couplets, these delightful poems attract the attention of children, amuse them, and arouse their abilities to imagine strange things and think of peculiar relationships. Furthermore, these poetic riddles

illustrate the multiple applications of words to things. Equally illustrated is the instability of language, its contextually determined meaning rather than its stable referents....Learning to work out the riddles or realize the referents is enjoyable, because the reader has the satisfaction of finding a meaning, but simultaneously the poems have fun with readers by exploiting the dissociation and estrangement that metaphor can bring to literal discourse. (Burlinson19)

Like Rossetti's, Shel Silverstein's poetry enriches the child's world in a specific manner. A highly eminent poet, playwright, cartoonist, and songwriter whose works are enjoyed by millions of children all over the world, Silverstein writes poems that smoothly instill noble values, foster creativity, and inspire positive attitudes, urging children to be the makers of their own decisions, the weavers of their own world, the initiators of new things, and the discoverers of wondrous experiences. In his poem 'Hug O' War', the poet instills in his young readers the values of caring, cooperation, loving others, and making 'everyone' feel important. The speaker is a child who thoughtfully maintains:

I will not play at tug o' war.

I'd rather play at hug o' war,

Where everyone hugs 
Instead of tugs,

Where everyone giggles

And rolls on the rug,

Where everyone kisses,

And everyone grins,

And everyone cuddles,

And everyone wins. (Where the Sidewalk Ends 19)

Instead of playing at the tug o' war game where some players are winners and the others are losers, the child speaker prefers to play at the hug o' war game in which everyone 'hugs', 'giggles', 'kisses', 'grins', 'cuddles', and 'wins'. Even when competing and conflict become inevitable, we should think of others, care for them, and allow them to feel happy and worthy. This is the message Silverstein raises in the poem. Symbolism is skillfully used by the poet to reveal the intended meaning of the lines. The tug o' war game where there are glad winners and sad losers symbolizes hurting others, overpowering them, disappointing them, and joining in a conflict with them. On the other hand, the hug o' war game signifies loving others, cooperating with them, and accepting them as sharers of the same joyful moments. The repetition of the word 'everyone' six times in the poem asserts the speaker's keenness to make every person content and satisfied, feeling like a winner. In other words, the love and kindness which the child speaker generously offers are so inclusive that they comprise all the children involved in the game.

'Put Something In' is an inspiring poem in which Silverstein encourages his child audience to be creative and to add something new to the world. The poem reads:

Draw a crazy picture,

Write a nutty poem,

Sing a mumble-gumble song, 
Enriching the Child's World in Selected Poems by Christina Rossetti, Shel

Silverstein, and Valerie Bloom: Insights into Children's Literature

Dr. Abdel Mohsen Ibrahim Hashim

مجلة و ادي النيل للاراسات والبحوث الإنسانية والاجتماعية والتريوية (مجلة علمية محكمة)

Whistle through your comb.

Do a loony-goony dance

'Cross the kitchen floor,

Put something silly in the world

That ain't been there before. (A Light in the Attic 22)

The poet asks children to let their light shine bright by expressing themselves and showing their creativity and uniqueness. Whether s/he draws, writes, sings, or dances, a child has something to create and offer. Even 'putting something silly in the world', the poet reminds his child reader, 'That ain't been there before', is considered a contribution that is highly admired and appreciated. The poem endows children with a wonderful feeling of confidence that guides them to be innovative and to try doing what they like in their own ways; even weird and silly things may be a way to creating great works that have not been there before. Noticeably, the poet uses a group of action verbs such as 'draw', 'write', 'sing', 'whistle', 'do', 'cross', and 'put' in order to encourage children to take action and show their talents.

Follow your intuition. Be yourself. Do not allow others to make your own decisions for you. These are the messages Silverstein sends to the child in his poem 'The Voice'. The poet addresses his child audience, pointing out:

There is a voice inside of you

that whispers all day long,

"I feel this is right for me,

I know that this is wrong."

No teacher, preacher, parent, friend

Or wise man can decide

What's right for you - just listen to

The voice that speaks inside. (Falling Up 38) 
مجلة وادي النيل للاراسات والبحوث الإنسانية والاجتماعية والتربوية (مجلة علمية محكمة)

(ISSN : 2536 - 9555)

Silverstein advises children to listen instinctively to 'the voice that speaks inside', urging them to ignore any external factors that may influence the way they judge matters. It is this inner light, this innate power, that enables the person to know what is right and what is wrong. No one else, no matter how 'wise' he or she is, can make our own decisions for us. So, we should base our choices on what we really want and what we inherently believe is right, simply because it is only we who can make the right judgment in the issues related to us. Once we do this, we can achieve success and lead a happy life. Throughout the lines, the poet uses personification, comparing the voice inside the child to a human being who whispers, feels, knows, and speaks. Onomatopoeia is also noted in the word 'whispers', referring to the voice that quietly 'speaks inside', guiding the child to the right path.

In 'Alice', Silverstein enriches the child's world through inviting children to take the initiative, try new things, discover unknown fields, and follow the model of Alice, the brave young girl who daringly experienced all these things and successfully accomplished the goal she had pursued. Recounting what happened with Alice, the poet writes in the poem:

She drank from a bottle called DRINK ME

And up she grew so tall,

She ate from a plate called TASTE ME

And down she shrank so small.

And so she changed, while other folks

Never tried nothin' at all. (Where the Sidewalk Ends 112)

Alluding to Lewis Carroll's Alice's Adventures in Wonderland, Silverstein describes how Alice found a bottle with a paper label reading 'DRINK ME' and how she then came by a cake in 'a plate called TASTE ME'. Here, the poet's idea is that you cannot know what will take place unless you 
Enriching the Child's World in Selected Poems by Christina Rossetti, Shel Silverstein, and Valerie Bloom: Insights into Children's Literature Dr. Abdel Mohsen Ibrahim Hashim

مجلة وادي النيل للاراسات والبحوث الإنسانية والاجتماعية والتربوية (مجلة علمية محكمة)

try and become bold. In the story, when Alice saw the bottle, she "ventured to taste it, and finding it very nice,... she very soon finished it off," Carroll writes, adding that when she found the cake, she decisively said, "Well, I'll eat it... and if it makes me grow larger, I can reach the key; and if it makes me grow smaller, I can creep under the door; so either way I'll get into the garden, and I don't care which happens" (11-13). Thus, the young girl, willing to take on the adventure, boldly drank from the bottle, and consequently, she grew bigger. Besides, she fearlessly ate the cake and surprisingly 'shrank so small'. As a result, the young heroine began to discover new things and encounter exciting experiences. More importantly, Alice 'changed,' unlike those people who are too afraid to try anything new. This is the lesson Silverstein teaches the child reader of the poem. To change, you have to try and be adventurous. In her shape-changing, Alice "experiences some of the changes in perspective that children frequently imagine: what it would be like to be larger, even gigantic, and what would it be like to be so small as not to exist" (MacDonald 53).

Asserting that positive thinking should be followed by positive action, Silverstein tells his child reader, "If the track is tough and the hill is rough, / thinking you can just ain't enough (Where the Sidewalk Ends 158). Urging his young readers to enjoy the moment they are in and make the most out of it, the poet affirms, "There are no happy endings. I Endings are the saddest part, / So just give me a happy middle / And a very happy start (Every Thing On It 22). Finally, Silverstein bids his child audience a highly inspiring farewell ${ }^{5}$ :

When I am gone what will you do?

Who will write and draw for you?

Someone smarter-someone new? 
مجلة وادي النيل للاراسات والبحوث الإنسانية و الاجتماعية والتربوية (مجلة علمية محكمة)

(ISSN : 2536 - 9555)

Someone better - maybe $Y O U$ !

(Every Thing On It 194)

Like Rossetti and Silverstein, the contemporary Jamaicanborn poet Valerie Bloom writes poetry that enriches the child's world in an interesting way. In 1979, Bloom left Jamaica and moved to England where she studied at the University of Kent and began establishing her fame as a performance poet. Now, she is one of the UK's finest children's authors. Her poems profoundly enrich young readers' knowledge, expressively present new information to them, sweetly develop their sense of humour, convincingly raise their environmental awareness, and greatly enhance their concern for the planet. 'Pet Shop' is a poem in which Bloom familiarizes her child audience with various kinds of animals, providing them with valuable information about each kind. The poem opens with these expressive lines that serve as an introduction to the whole poem:

So you want to get yourself a pet?

Well, you've come to the right place,

I've got just the group of animals

To put a broad smile on your face.

(Jaws and Claws 4)

The poet tells children that in her 'pet shop', they will find all that they want, as the shop offers a variety of animals that will make them happy and excited. Giving information about the animals she has, the speaker states:

Here's a green anaconda

Straight from the Amazon,

She'll be happy if you feed her

With a deer or a caiman.

(Jaws and Claws 4) 
Enriching the Child's World in Selected Poems by Christina Rossetti, Shel

Silverstein, and Valerie Bloom: Insights into Children's Literature Dr. Abdel Mohsen Ibrahim Hashim

مجلة وادي النيل للاراسات والبحوث الإنسانية والاجتماعية والتربوية (مجلة علمية محكمة)

The lines acquaint the child reader with an animal named the green anaconda, brought by the speaker from the Amazon drainage basin in South America. Belonging to the boa family, "green anacondas are large, heavy-bodied snakes with a head that seems somewhat small compared to the size of the body... The ground color of these huge snakes is typically olive, but can be olive-brown, olive-gray, or even bluish gray" (Strimple 46). In addition to deer and caimans which Bloom mentions in the poem, green anacondas feed on fish, peccaries, capybara, tapirs, turtles, birds, sheep, and dogs.

The speaker's pet shop also has alligators and crocodiles. The poet indicates:

I've got alligators from the Everglades,

A crocodile from the Nile,

You surely can't resist those tears,

Or that inviting smile? (Jaws and Claws 4)

Excitedly, children are introduced to alligators which are found in the Everglades, a region of tropical wetlands in the south of Florida. There are two famous species of alligators, the American alligator, and the Chinese alligator. The speaker's pet shop also contains a crocodile brought from the River Nile, the longest river in the world which flows northward passing many African countries till it reaches Egypt and drains into the Mediterranean Sea. There are many kinds of crocodiles such as the American crocodile, the Orinoco crocodile, the freshwater crocodile, the Philippine crocodile, the Cuban crocodile, the West African crocodile, and the saltwater crocodile. The stanza not only stimulates children to know about the kinds and places of these animals, but it also invites them to think of the similarities and differences 
مجلة وادي النيل للاراسات والبحوث الإنسانية والاجتماعية والتربوية (مجلة علمية محكمة)

(ISSN : 2536 - 9555)

between alligators and crocodiles. Both alligator and crocodile are reptiles that belong to the crocodile family. Though they look similar, they differ from each other in some aspects. Compared to alligators, "crocodiles have longer and thinner snouts...Alligators are freshwater animals, while crocodiles [tend to] live in saltwater. The teeth of a crocodile are visible, even when the crocodile's mouth is closed, while alligator teeth are invisible until the mouth is open" (Stetson). The poet cleverly warns children not to be deceived by these animals' fake tears and tricky smile. Undoubtedly, all this information enriches young readers' knowledge.

Other animals the poem familiarize children with are "poison dart frogs" that live in "the jungles of Peru," a "blueringed octopus," "jellyfish," "a coyote," "a brown bear," "a male Komodo dragon," a "red-backed spider," and a "vampire bat" (Jaws and Claws 5). Undoubtedly, acquainting children with all these kinds of animals widens their horizon, enriches their knowledge, stimulate them to search and know more about each animal the poet refers to.

Simple humour is a dominant feature in Bloom's poetry for children. In her poem titled 'I Asked the River', the speaker joins with the river in a funny conversation. The poet writes:

'Why do you sing?' I asked the river, 'Such a sweet and happy tune?'

'Because,' the river smiled,

'I'm having lunch with the sea at noon.'

'Why do you laugh?' I asked the river,

'You'll share the joke I suppose?'

'I woke the mountain,' the river grinned,

'By tickling his toes.' (Hot Like Fire 84)

Personifying the river as a human being who can listen, speak, and reply to her questions, the poet asks her addressee about 
Enriching the Child's World in Selected Poems by Christina Rossetti, Shel Silverstein, and Valerie Bloom: Insights into Children's Literature Dr. Abdel Mohsen Ibrahim Hashim

مجلة وادي النيل للاراسات والبحوث الإنسانية والاجتماعية والتربوية (مجلة علمية محكمة)

the reason which makes him feel happy and sing such sweet melodies while he is running his course. The river smiles and jokily states that he has a meeting with the sea and is going to have lunch with him 'at noon'. The river further remembers a humorous situation and cannot stop laughing. Curious to know why the river laughs, the speaker requests that he shares the joke with her. Humorously, the river indicates that he had a comic incident with the mountain as he lightly touched the mountain's toes with his fingers, therefore making him wake up suddenly. Again the poet personifies the mountain as a human and thus adds more depth to the humor evoked by the poem. Of course, this funny poem attracts the attention of children and arouses their laughter. Reviewing Bloom's Hot Like Fire, the collection of poetry that contains the abovequoted poem, Gillian Engberg points out how the poet expertly "writes with simple humor and a rolling beat about pets, food, family annoyances, Imaginative games, and the natural world" and how her "sunny, often absurd humor and storytelling style create... winning poems" (406).

Suddenly, the happy, singing, and smiling river shudders, groans and sighs. Bloom illustrates, "The song of the streams and the laughter died, / And it whispered sadly, 'I can't, I can't,' / As it limped along like an ancient aunt" (Hot Like Fire 84). Drawing the attention of her young readers to a serious environmental issue, the poet completes the tale:

'My lungs are clogged,' the river moaned,

'And I can hardly breathe.'

'Perhaps a rest,' I told the river,

'Would help to clear your head.'

'I cannot rest,' the river said,

'There's garbage in my bed.' 
'What's this garbage,' I asked, disturbed,

'Which is clogging up your sand?'

'Poisonous waste and wrappers like this,

Which just fell from your hand.' (Hot Like Fire 85)

Unable to run its course, the river becomes slow and 'can hardly breathe', as if it were going to die. The simile in 'it limped along like an ancient aunt' indicates how grave the predicament of the river is. Sympathizing with the distressed river, the speaker feels 'disturbed' and suggests that some rest may make matters better and help the river recover and resume its way. However, the river sorrowfully maintains that it cannot rest because of the trash that blocks its lungs, clogs up its sand, and hinders its path. Then, the river shocks the speaker by telling her that she is the main reason behind all this suffering because she has uncaringly thrown 'poisonous waste and wrappers' in its water.

Thus, the poet effectively raises the child's environmental awareness. She does so in an indirect way, as she does not write in her poem, 'children, you should not pollute rivers'. Instead, she simply presents the problem and convincingly makes her young readers take part in it and see its consequences step by step till they finally realize by themselves that it is we, humans, who pollute the water of the river, insult nature, and make its elements suffer greatly. Acting in such a skillful manner, Bloom makes children feel their responsibility towards the natural world. The child who reads such a poem will surely be careful not to pollute water or humiliate nature. Indeed, Bloom's 'I Asked the River' is a good example of ecological poetry that brings into sharp light the need of parents and educators to promote children's concern for the environment and the dangers that threaten its resources nowadays ${ }^{6}$. As Yeter Simsekli remarks, 
Enriching the Child's World in Selected Poems by Christina Rossetti, Shel

Silverstein, and Valerie Bloom: Insights into Children's Literature Dr. Abdel Mohsen Ibrahim Hashim

مجلة وادي النيل للاراسات والبحوث الإنسانية والاجتماعية والتربوية (مجلة علمية محكمة)

In [the] 21 st century, there has been a significant increase in the amount of both regional and global environmental problems. These worrying changes around us not only bring the precautions to be taken for these problems into the forefront but also enhance the importance of....rais[ing] environmental awareness of today's children. (222)

The importance of forests for the ecological system is stressed in 'Forest', a poem in which Bloom writes:

Forest,

Home to Baboon,

Elephant, Leopard. The

Giants of the jungle. And home

To ants. (Mighty Mountains, Swirling Seas 2)

As the lines reveal, the forest is the shelter of animals of all sizes and shapes. It is not only the 'home' of baboons, leopards, and the huge animals that the poet describes as the 'giants of the jungle' like, for example, 'elephants', rhinos, and giraffes, but it is also the safe place of the small and the helpless such as rabbits, tortoises and 'ants'. The contrast between 'giants' and 'ants' suggests that the forest is a comprehensive, natural place, a 'home', that includes all sorts of animals without discrimination between the large and the tiny or the strong and the weak. This depiction of the forest and its significance as the 'home' of animals makes young readers of the poem recognize their responsibility as human beings in preserving forests and keeping all life forms in it secure and protected.

In Summary, Rossetti, Silverstein, and Bloom provide varied insights into enriching the child's world. Rossetti's poetry outstandingly beautifies the world of childhood with 
the warmth of maternal love and care, enhances children's aesthetic taste, arouses their curiosity, and stimulates their capabilities to work imaginatively. These meanings are embodied in poems like 'Who Has Seen the Wind?', 'Love me - I love you', 'Crying, My Little One, Footsore and Weary', 'The Rainbow', 'Kookoorookoo! Kookoorookoo', 'Song' ('Two Doves upon the Selfsame Branch'), 'A Pin Has a Head, But Has No Hair', and 'A City Plum'.

On the other hand, Silverstein's poetry interestingly teaches children valuable life lessons, and inculcates good values and moral ideals in them. Furthermore, it develops the spirit of adventure in young readers and invites them to discover new worlds and get engaged in enjoyable experiences. It also addresses their creative powers, promotes their positivity in both thinking and action, and encourages them to be active, thoughtful, self-dependent, innovative, and unique. Of the poems revealing these ideas are 'Early Bird', 'Hug O' War', 'Put Something In', 'The Voice', 'Alice', 'The Little Blue Engine', 'Happy Ending?', and 'When I am Gone'.

As for Bloom's poetry, it remarkably enriches the child's background, experience, and knowledge through the new information the poet presents for her child reader. Responding to today's environmental crises which are often caused by human hands, Bloom attempts to equip the young readers of her poems with ideas and information about nature and its beautiful elements such as forests, oceans, seas, and rivers which people deliberately pollute and degrade. In this way, the poet proficiently increases children's awareness of the environment and makes them feel the urgent need to preserve and respect it. Examples of the poems dealing with these issues are 'The River', 'Pet Shop', 'I Asked the River', and 'Forest'. 
Enriching the Child's World in Selected Poems by Christina Rossetti, Shel Silverstein, and Valerie Bloom: Insights into Children's Literature Dr. Abdel Mohsen Ibrahim Hashim

مجلة وادي النيل للاراسات والبحوث الإنسانية والاجتماعية والتربوية (مجلة علمية محكمة)

\section{Notes}

1. A hornbook is an old teaching aid consisting of a leaf of paper fixed to a wooden frame and protected by a thin plate of horn ("Definition of hornbook"). For more information on hornbooks, see History of the Horn-book (1896) by Andrew W. Tuer.

2. Aesop's Fables is a collection of tales that were originally written by the Greek fabulist and storyteller Aesop.

3. Le Morte d'Arthur or The Death of Arthur is a compilation of stories about the legendary British King Arthur and the Knights of the Round Table.

4. In her book titled Christina Rossetti, Kathryn Burlinson sheds light on the use of riddles in Rossetti's poetry for children, showing how the poet, as a child, liked riddles and read about them in works such as Batchelar's Pleasant Exercises for Little Minds (1820), and how the poet, when she grew up, started inventing riddles like that one she sent in a letter to her nephew Arther (19).

5. For a thought-provoking appreciation of Silverstein's poetry for children, see Ruth K. MacDonald's Shel Silverstein (1997).

6. In a reply to an inquiry made by the researcher to Valerie Bloom via email about the poet's works that best develop children's concern for the environment, Bloom pointed out that the environment is an important theme in her poems written for children, particularly the poems included in her three poetry collections, Hot Like Fire and Other Poems, Jaws and Claws and Things with Wings: Poems by Valerie Bloom, and Mighty Mountains, Swirling Seas ("Re: General Inquiry"). 
مجلة وادي النيل للاراسات والبحوث الإنسانية والاجتماعية والتربوية (مجلة علمية محكمة)

(ISSN : 2536 - 9555)

\section{Works Cited}

Androne, Mihai. "Notes on John Locke's Views on Education." Procedia - Social and Behavioral Sciences, vol.137, 2014, pp. $74-79$.

Bloom, Valerie. Jaws and Claws and Things with Wings: Poems by Valerie Bloom. Illustrated by Matt Robertson. HarperCollins, Big Cat Poetry, 2013.

---. Hot Like Fire and Other Poems. Illustrated by Debbie Lush. Bloomsbury, Publishing Plc, 2009.

---. Let Me Touch The Sky: Selected Poems for Children. Illustrated by Ashley Bloom. Macmillan Children's Books, 2000.

---. Mighty Mountains, Swirling Seas. Illustrated by Alessandra Cimatoribus. HarperCollins, Big Cat Poetry, 2015.

---."Re: General Inquiry." Received by Abdel Mohsen Hashim, 17 May 2019.

Burlinson, Kathryn. Christina Rossetti. Northcote House Publishers Ltd, 1998.

Carroll. Lewis. Alice's Adventures in Wonderland. Illustrated by John Tenniel. Digital, Scanning Inc, 2007.

Carson, Rachel. The Sense of Wonder. Illustrated by Charles Pratt. Harper \& Row, 1965.

"Definition of hornbook." Oxford Dictionaries. en.oxforddictionaries.com/definition/hornbook. Accessed 19 Mar. 2019.

Engberg, Gillian. "Review of Hot Like Fire, by Valerie Bloom." Booklist, vol. 100, no. 4, Oct. 2003, p. 406.

Hunt. Peter, editor."Introduction: The Expanding World of Children's Literature Studies." Understanding Children's Literature, 2nd ed. Routledge, 2005, pp.1-14. 
Enriching the Child's World in Selected Poems by Christina Rossetti, Shel Silverstein, and Valerie Bloom: Insights into Children's Literature Dr. Abdel Mohsen Ibrahim Hashim

مجلة وادي النيل للاراسات والبحوث الإنسانية والاجتماعية والتربوية (مجلة علمية محكمة)

Kumberg, Krista "Children's Literature in the 21st Century." Estonica.org - Encyclopedia about Estonia. www.estonica.org/en/Estonian_children\%E2\%80\%99s lite rature/Children $\% \mathrm{E} 2 \% 80 \% 99 \mathrm{~s}$ literature in the 21st cent ury/. Accessed 29 Apr. 2019.

MacDonald, Ruth K. Shel Silverstein. Twayne Publishers, 1997.

Murphy, Daniel. Comenius: A Critical Re-Assessment of His Life and Work. Irish Academic Press, 1995.

Nodelman, Perry. The Pleasures of Children's Literature. Longman Publishing Group, 1992.

Petersen, Roger Bruce. My Life in Story: A One-Man Play about Hans Christian Andersen. 2008. Drew U, Ph.D. dissertation. ProQuest, www.search- proquest-com.sdl. idm.oclc.org/docview/304637954?accountid=142908.

Rossetti, Christina. Goblin Market and Other Poems. CreateSpace Independent Publishing Platform, 2017.

---. Poems and Prose. Edited with an Introduction and Notes by Simon Humphries. Oxford UP, 2008.

---. Selected Poems: Cristina Rossetti. Edited with an Introduction and Notes by Dinah Roe. Penguin Books, 2008.

---. Sing-Song: A Nursery Rhyme Book. Living Book Press, 2018.

---. The Poetical Works of Christina Georgina Rossetti. With Memoir and Notes by William Michael Rossetti. Adamant Media Corporation, 2006.

Rosenthal, Lynne. "Review of John Locke and Children's Books in Eighteenth-Century England, by Samuel F. Pickering." Children's Literature Association Quarterly, vol. 8 no. 2, 1983, pp. 36-38. Project MUSE, doi:10.1353/chq.0.0372 
مجلة وادي النيل للار اسات والبحوث الإنسانية والاجتماعية والتربوية (مجلة علمية محكمة)

(ISSN : 2536 - 9555)

www.muse.jhu.edu/article/248221/pdf. Accessed 15 Feb. 2019.

Silverstein, Shel. A Light in the Attic: Poems and Drawings by Shel Silverstein. HarperCollins, 2005.

---. Every Thing On It: Poems and Drawings by Shel Silverstein. HarperCollins, 2011.

---. Falling Up: Poems and Drawings by Shel Silverstein. HarperCollins, 1996.

---.. Where the Sidewalk Ends: The Poems and Drawings of Shel Silverstein. HarperCollins, 2014.

Simsekli, Yeter. "An Implementation to Raise Environmental Awareness of Elementary Education Students." Procedia Social and Behavioral Sciences, vol.191, 2015. pp. 222 226.

Stetson, Chad. "Alligator \& Crocodile Similarities."

SCIENCING.www.sciencing.com/alligator-crocodilesimilarities- 8626864.html. Accessed 23 Apr. 2019.

Stevenson, Laura C. "Literary Ladders in the Golden Age of Children's Books." The Sewanee Review, vol. 119, no. 3, 2011. pp. 428-444.

Strimple, Pete. "The Green Anaconda, Eunectus Murinus (Linnaeus)." Litteratura Serpentium, vol. 13, no. 2, 1993, pp.46-50.

Tokunaga, Satoko."Early English Printing and the Hands of Compositors." International Journal of English Studies (IJES), vol.5, no. 2, 2005. pp. 149-160. 